\title{
EKSPLORASI SENYAWA BIOAKTIF ALGA COKELAT Sargassum sp. AGARDH SEBAGAI ANTIOKSIDAN DARI PESISIR BARAT ACEH
}

\author{
Mohamad Gazali ${ }^{1 \star}$, Nurjanah ${ }^{2}$, Neviaty P. Zamani ${ }^{3}$ \\ ${ }^{1}$ Program Studi Ilmu Kelautan, FakultasPerikanan dan Ilmu Kelautan Universitas Teuku Umar \\ ${ }^{2}$ DepartemenTeknologi HasilPerairan, Fakultas Perikanan dan Ilmu Kelautan, Institut Pertanian Bogor \\ Institut Pertanian Bogor \\ ${ }^{3}$ Departemen Ilmu dan Teknologi Kelautan, Fakultas Perikanan dan Ilmu Kelautan, Institut Pertanian \\ Bogor \\ Jalan Alue Peunyareng, Meulaboh, Aceh Barat 23615, Aceh, Telepon (0655) 7003087 \\ *Korespodensi: mohamadgazali@utu.ac.id \\ Diterima: 11 November 2017/ Disetujui: 18 April 2018
}

Cara sitasi: Gazali M, Nurjanah, Zamani NP. 2018. Eksplorasi senyawa bioaktif alga cokelat Sargassum sp. Agardh sebagai antioksidan dari Pesisir Barat Aceh. Jurnal Pengolahan Hasil Perikanan Indonesia. 21(1): $167-178$.

\begin{abstract}
Abstrak
Alga cokelat merupakan salah satu jenis makroalga laut yang mendominasi kawasan pesisir Barat Aceh. Penelitian ini bertujuan untuk melakukan eksplorasi senyawa bioaktif alga cokelat Sargassum sp. sebagai sumber antioksidan. Penelitian dilakukan secara deskriptif. Pengujian terdiri dari analisis proksimat, senyawa aktif, total fenol, aktivitas antioksidan metode DPPH dan perhitungan rendemen ekstrak. Hasil penelitian menunjukkan komposisi kimia yang paling dominan terdiri dari kadar abu 52,74\% dan kadar karbohidrat 23,77\%. Rendemen ekstrak Sargasuum sp. dengan pelarut etanol 0,565\%, etil asetat 0,420\% dan n-heksan 0,265\%. Kadar total fenol etanol ektrak 563,22 mg GAE/g, etil asetat ekstrak 13,48 mg GAE/g, n-heksan ekstrak 30,610 mg GAE/g. Aktivitas antioksidan etanol ekstrak dengan $\mathrm{IC}_{50}=239,51 \mathrm{mg} / \mathrm{L}$, etil asetat ekstrak 68,89 mg/L dan n-heksan ekstrak $148.16 \mathrm{mg} / \mathrm{L}$. Ekstrak Sargassum sp. terdeteksi mengandung fenol, alkaloid dan triterpenoid.
\end{abstract}

Kata Kunci: alga cokelat, antioksidan, kandungan total fenol, proksimat

\section{The Exploration of Bioactive Compound to Brown Algae Sargassum sp. Agardh as Antioxidant from West of Aceh Coastal}

\begin{abstract}
Brown algae is one of the dominant species in the West of Aceh coastal. This study aims to explore the bioactives of Sargassum sp. as a source of antioxidants from west of Aceh coastal. The research was conducted descriptively. The test consisted of proximate analysis, active compound, total phenol, antioxidant activity of DPPH method and calculation of yield of extract. The results showed the most dominant chemical composition consisted of ash content $52.74 \%$ and carbohydrate content $23.77 \%$. The yield ethanol exstract $0.565 \%$, ethyl acetate $0.420 \%$ and n-hexane $0.265 \%$. total phenol ethanol extract 563,22 mg GAE / g, ethyl acetate extract $13.48 \mathrm{mg} \mathrm{GAE} / \mathrm{g}$, n-hexane extract $30.610 \mathrm{mg}$ GAE/g. Activity of antioxidant ethanol extract $\mathrm{IC}_{50} 239.51 \mathrm{mg} / \mathrm{L}$, ethyl acetate extract $68,89 \mathrm{mg} / \mathrm{L}$ and $\mathrm{n}$-hexan extract $148.16 \mathrm{mg} / \mathrm{L}$. Sargassum sp. extract detected containing phenol, alkaloids and triterpenoids
\end{abstract}

Keywords: antioxidant, brown algae, proximate, total phenolic content 


\section{PENDAHULUAN}

Makroalga laut atau yang lebih dikenal dengan "rumput laut" merupakan salah satu potensi biodiversitas hayati laut yang memberikan nilai tambah (value added) dalam bidang farmasi dan kosmetika. Distribusi makroalga laut yang tersebar luas di seluruh pesisir Barat Selatan Aceh dengan karakteristik perairan yang masih sesuai dengan pertumbuhan dan perkembangan makroalga laut dan kurangnya tingkat pencemaran laut. Makroalga laut belum dimanfaatkan secara optimal disebabkan minimnya kajian ilmiah terkait potensi makroalga laut yang berguna bagi masyarakat pesisir Aceh.

Sumber antioksidan alami memainkan peranan penting dalam melawan stres oksidatif yang berkaitan dengan penyakit degeneratif di antaranya kanker, penyakit kardiovaskular, diabetes, penyakit alzheimer dan proses penuaan (Wong et al. 2006; Naczk dan Shahidi 2006; Mudgal et al. 2010). Senyawa aktif yang berfungsi sebagai antioksidan khususnya senyawa fenolik yang ditemukan di dalam sayur-sayuran dan buahbuahan menjadi perhatian karena berpotensi dalam pencegahan penyakit pada manusia.

Alga cokelat memiliki kandungan karbohidrat, protein, abu, air, vitamin dan mineral dalam bentuk makro dan mikro elemen yaitu kalium (K), natrium $(\mathrm{Na})$, magnesium (Mg), fosfat (P), iodin (I) dan besi (Fe) (Syad et al. 2013; Cardoso et al. 2015). Alga cokelat mengandung metabolit sekunder yang bermanfaat bagi kesehatan antara lain senyawa alkaloid, glikosida, tanin dan steroid yang banyak digunakan dalam pengobatan dan industri farmasi (Jeeva et al. 2012) serta senyawa fenolik dan flavonoid yang memiliki aktivitas penghambatan oksidasi LDL, Angiotensin Coverting Enzyme (ACE), a-amilase, a-glukosidase (Nagappan et al. 2017) dan berpotensi memberikan efek terapeutik serta perlindungan terhadap beberapa penyakit degeneratif terutama kanker (Padua et al. 2015)

Rumput laut sebagai sumber antioksidan sudah diteliti di antaranya rumput laut sebagai bahan baku kosmetik (Dolorosa et al. 2017; Luthfiyana et al. 2017;
Maharany et al. 2017; Nurjanah et al. 2015; Yanuarti et al. 2017). Rumput laut sebagai sediaan garam rumput laut bagi pasien hipertensi (Diachnty et al. 2017; Nufus et al. 2017), sumber nutraseutika dari ekstrak Sargasum aquifolium (Firdaus 2013). Makroalga laut yang berasal dari pesisir barat Aceh belum dieksplorasi terkait bioaktivitasnya. Diachanty et al. (2017) melaporkan bahwa 3 jenis rumput laut cokelat yaitu S. polycystum, P. minor dan T. conoides memiliki aktivitas antioksidan dengan nilai $\mathrm{IC}_{50} 1,9-9,6 \mathrm{mg} / \mathrm{mL}$, FRAP 70,643-105,357 $\mu \mathrm{mol}$ troloks/g dan CUPRAC 85,268-291 $\mu$ moltroloks/g.

Sargassum sp. merupakan rumput laut cokelat tropis dan subtropis yang hidup pada daerah subtidal dan intertidal yang terdiri dari 150 spesies (Olabarria et al. 2005). Distribusi dan struktur populasi spesies sargassum dipengaruhi oleh suhu air, tingkat pasang surut, gerakan air dan tipe substrat (misalnya berbatuan) (Aterweberhan et al. 2005).

Sargassum sp. sudah dikaji secara luas menunjukkan potensi antioksidan yang tinggi secara in vitro (Zubia et al. 2008; Budhiyanti et al. 2011). Senyawa fenolik merupakan salah satu antioksidan yang paling efektif dalam alga cokelat (Nagai dan Yukimoto 2003). Kandungan fenolik pada alga cokelat sebesar 20-30\% berat kering (Ragan dan Glombitza 1986). Studi yang menunjukkan bahwa florotanin merupakan senyawa fenolik utama yang terdeteksi didalam alga cokelat (Koivikko 2008). Florotanin adalah kelompok senyawa fenolik yang dibentuk oleh polimerasi unit monomer floroglusinol (1,3,5 trihydroxybenzena) dan disintensi dalam jalur asetat malonat dalam makroalga (Ragan dan Glombitza 1986; Arnold dan Targett 2000; Koivikko et al. (2005) membagi florotanin ke dalam tiga bagian, florotanin terlarut dari matrik alga atau florotanin sitoplasma, florotanin yang berikatan dengan dinding sel yang melekat pada membran dinding sel dan dapat terlepas dan terbawa oleh air laut. Budhiyanti et al. (2011) menyatakan bahwa aktivitas antioksidan rumput laut bersumber dari senyawa yang berikatan dengan membran 
pada dinding sel.

Makroalga laut banyak tersebar di wilayah pesisir Barat Aceh, kebanyakan menempel pada batuan karang mati sehingga mudah terpapar oleh radiasi ultraviolet. Alga cokelat merupakan salah satu makroalga laut yang cukup mendominasi kawasan pesisir pantai Barat Aceh tepatnya di pesisir pantai Lhok Bubon Kabupaten Aceh Barat. Banyak masyarakat lokal yang melakukan rekreasi dan pemancingan di kawasan tersebut, merupakan salah satu objek wisata pantai yang disukai masyarakat lokal. Wilayah pesisir barat Aceh memiliki ombak yang cukup besar pada musim barat karena berhadapan langsung dengan Samudera Hindia. Tujuan penelitian ini adalah untuk melakukan eksplorasi senyawa bioaktif alga cokelat Sargassum sp. sebagai antioksidan dari Pesisir Barat Aceh

\section{BAHAN DAN METODE Bahan dan Alat}

Bahan yang digunakan dalam penelitian ini yaitu simplisia Sargassum sp. Bahankimia yang digunakanuntukanalisisyaituetanol pa (Merck), etil asetat pa (Merck) dan n-heksan pa (Merck), DPPH (2,2-diphenil-2-picryl hydrazil (Sigma-Aldrich)), larutan $\mathrm{HCl} 2 \mathrm{~N}$ (Merck), Asam askorbat (Merck), tablet Kjeldahl (Merck), $\mathrm{H}_{3} \mathrm{BO}_{3} \quad 2 \%$ (Merck), indikator Brom Cresol Green-Methyl Red
(Merck), $\mathrm{NaOH} 40 \%$ (Merck), $\mathrm{HNO}_{3}$ pekat (Merck), $\mathrm{HClO}_{4}$ (Merck), $\mathrm{HF}$ (Altech), $\mathrm{NaBH}_{4}$ (Sigma-Aldrich), akuades, pereaksi Meyer (larutan A $1,36 \mathrm{~g} \mathrm{HgCl}_{2}$ (Sigma-Aldrich) dilarutkan dalam $60 \mathrm{~mL}$ akuades, larutan B 0,5 g KI (Merck) dilarutkan dalam $10 \mathrm{~mL}$ akuades) pereaksi Dragendroff (larutan A 0,85 g bismuth nitrat (Sigma Aldrich), $2 \mathrm{~mL} \mathrm{HCl}$ pekat (Merck) dan $10 \mathrm{~mL}$ akuades, larutan $\mathrm{B}$ $8 \mathrm{~g} \mathrm{KI}$ (Merck) dan $10 \mathrm{~mL}$ akuades, pereaksi Wagner (2,5 g I2, 3 g KI(Merck) dan $10 \mathrm{~mL}$ akuades), eter (Merck), FeCl3 (Merck), etanol PA $99,9 \%$ (Merck), Alat yang digunakan yaitu centrifuge (Hermle Z $383 \mathrm{~K}$ ), rotary vacum evaporator (Heidolph WB 2000), microplate (Nunc), alat-alat gelas (Pyrex), mikro pipet (Gilson) waterbath (SWBR17), pipet mikro (Eppendorf) dan AAS (Atomic Absorbtion Spectrofotometer) (Shimadzu AA-7000), spectro UV-Vis RS Spectrophotometer (UV2500).

\section{Pengambilan sampel}

Pengambilan sampel alga cokelat Sargassum sp. Berlokasi di Pantai Lhok Bubon Kabupaten Aceh Barat (Gambar 1). Sargassum sp. diambil pada bulan April 2017 pada kedalaman sekitar $\pm 1 \mathrm{~m}$ di zona intertidal pesisir Barat Aceh. Sampel yang sudah dikumpulkan dibawa ke Laboratorium Perikanan Universitas Teuku Umar untuk

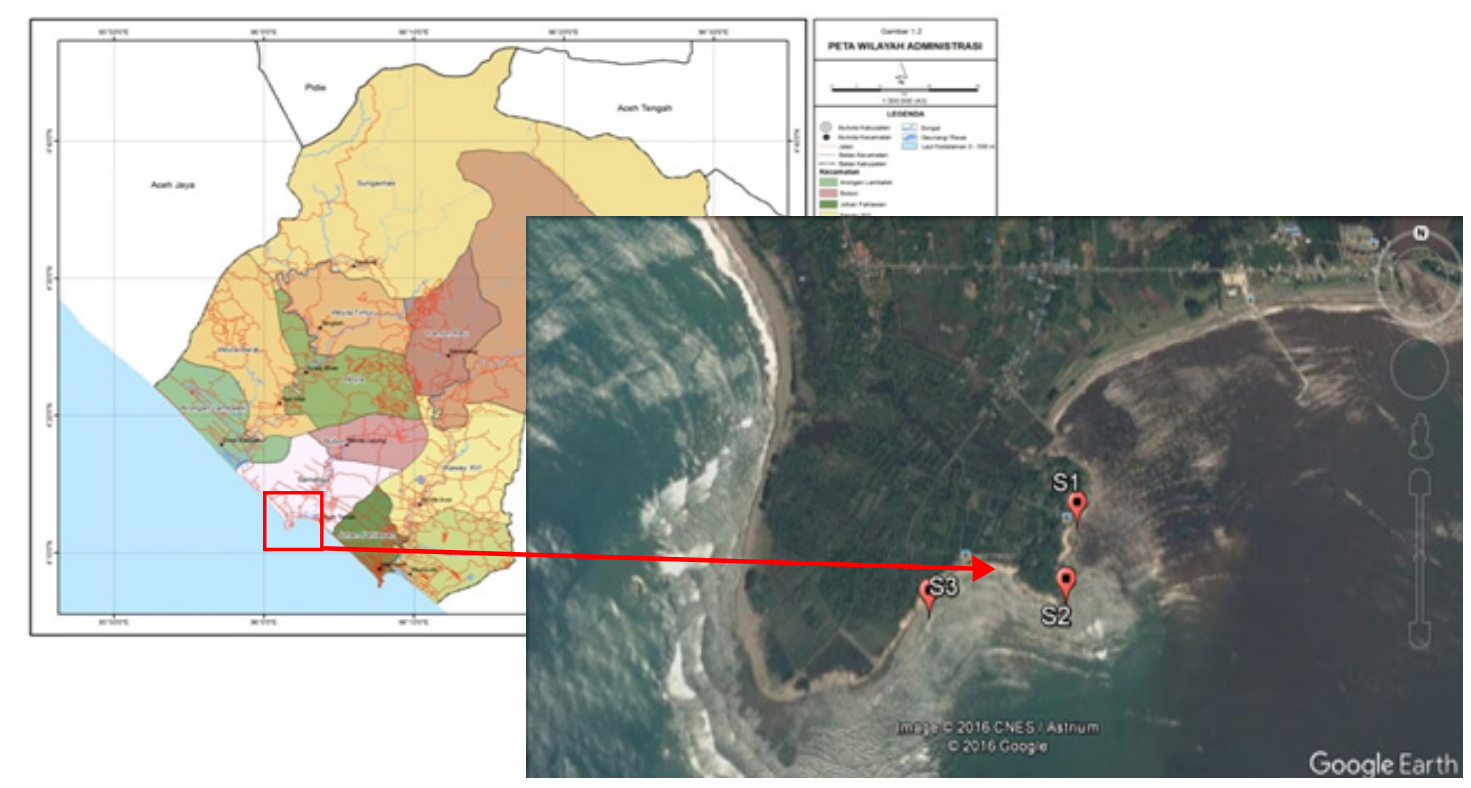

Gambar 1 Lokasi pengambilan sampel

(Figure 1 Sampling site) 
identifikasi spesies kemudian sampel dibersihkan dari substratnya dan dicuci hingga bersih dengan menggunakan air tawar.

\section{Komposisi kimia}

Komposisi kimia meliputianalisis kadar air, abu, karbohidrat, protein, dan lemak ditentukan berdasarkan analisis proksimat yang mengacu pada metode AOAC (2005).

\section{Ekstraksi alga cokelat Sargassum sp.}

Sampel dikeringkan di bawah sinar matahari selama \pm 4 hari. Sampel yang telah kering dipotong-potong kemudian dihaluskan dengan menggunakan blender hingga menjadi serbuk simplisia kering. Simplisia ditimbang sebanyak $50 \mathrm{~g}$ dan dimasukkan ke dalam gelas erlenmeyer. Maserasi dilakukan dengan perbandingan 1:3 menggunakan etanol p.a, etil asetat p.a dan $n$-heksan p.a masing-masing dan direndam selama $2 \times 24$ jam. Perendaman berfungsi untuk menarik keluar senyawasenyawa organik yang terkandung dalam simplisia. Larutan disaring menggunakan kertas saring biasa dan dipekatkan dengan evaporator hingga terbentuk ekstrak kental.

\section{Komponen bioaktif ekstrak Sargassum sp.}

Uji fitokimia merupakan uji pendahuluan untuk mengetahui kandungan senyawa aktif seperti alkaloid, flavonoid, fenol hidrokuinon, steroid, triterpenoid, saponin dan tanin secara kualitatif (Harborne1987)

\section{Analisis kandungan total fenol}

$\begin{array}{crr}\text { Pengukuran } & \text { kandungan } & \text { total } \\ \text { fenol dilakukan berdasarkan metode }\end{array}$ Andarwulan et al. (1999) dengan modifikasi. Pembuatan standar asam galat dilakukan dengan melarutkan $5 \mathrm{mg}$ asam galat ke dalam akuades menggunakan labu takar 25 $\mathrm{mL}$. Kemudian dari larutan tersebut, dibuat standar dengan konsentrasi 10, 20, 30, 40, 50, 60 dan 70. Pengujian kandungan total fenol dilakukan dengan melarutkan $20 \mathrm{mg}$ ekstrak dengan pelarut etanol, etil asetat dan n-heksan masing-masing dalam labu takar $25 \mathrm{~mL}$ dan dihomogenisasi dengan shaker.
Ekstrak diambil 0,5 mL dari larutan tersebut dan ditambahkan dengan pereaksi Follin Ciocalteu 50\% sebanyak $1 \mathrm{ml}$, dan didiamkan 5 menit setelah itu ditambahkan $1 \mathrm{ml}$ $\mathrm{Na}_{2} \mathrm{CO}_{3} 5 \%$ dan dihomogenisasi dalam gelap selama 1 jam. Nilai absorbansi diukur pada panjang gelombang $725 \mathrm{~nm}$ menggunakan spektrofotometer UV-VIS.

\section{Aktivitas antioksidan dengan metode DPPH}

Uji aktivitas antioksidan menggunakan metode DPPH (1-diphenyl-2-picrylhydrazyl) (DPPH) dengan konsentrasi 0,1 mM mengacu pada metode Chan et al. (2002) yang dimodifikasi. Sampel ekstrak kasar rumput laut dilarutkan masing-masing dalam n-heksana, etil asetat dan etanol dengan konsentrasi 10, 20, 30, 40, $50 \mathrm{ppm}$. Asam askorbat digunakan sebagai kontrol positif dengan konsentrasi 1, 2, 3, 4 dan 5 ppm. Aktivitas antioksidan masing-masing sampel dinyatakan dengan persentase penghambatan radikal bebas yang dihitung dengan rumus :

Inhibisi (\%) $\frac{\text { Absorbansi blanko-Absor-Absorbansi Sampel }}{\text { Absorbansi blanko }} \times 100 \%$

\section{Analisis Data}

Data dianalisis secara deskriptif, semua datadinyatakan sebagai mean, data yang diperoleh dihitung menggunakan Microsoft excel.

\section{HASIL DAN PEMBAHASAN}

Alga cokelat Sargassum sp. diperoleh dari Pesisir Barat Aceh di Desa Lhok Bubon Kecamatan Samatiga Kabupaten Aceh Barat. Sargassum sp. banyak menempel pada substrat batuan karang mati. Faktor-faktor antropogenik pada perairan tersebut belum mempengaruhi perkembangan makroalga karena pesisir tersebut merupakan salah satu lokasi wisata pantai bagi masyarakat lokal. Sargassum sp. dimanfaatkan oleh masyarakat pesisir sebagai sayuran dan pakan ternak, saat ini, informasi terkait bioprospeksi dari makroalga asal pesisir Barat Aceh masih minim. 
Tabel 1Komposisi proksimat Sargassum sp. kering (Table 1 The proximate composition of dried Sargassum sp.)

\begin{tabular}{cc}
\hline Parameter/Parameters & Rataan/Average (\%) \\
\hline Kadar air/Moisture content & $10.54 \pm 0.25$ \\
Kadar abu/Ash content & $52.74 \pm 0.53$ \\
Kadar protein/Protein content & $2.53 \pm 0.15$ \\
Kadar lemak/Fat content & $0.79 \pm 0.04$ \\
Kadar karbohidrat/Carbohydrate content & 23.77 \\
\hline
\end{tabular}

\section{Komposisi Kimia}

Komposisi kimia Sargassum sp. disajikan pada Tabel 1. Kadar air pada Sargassum sp. 10,54. Sargassum sp. kering memiliki kadar abu yaitu $52 \%$, kadar protein $2,5 \%$, kadar lemak $0,79 \%$.

Tabel 1 menunjukkan kadar air yang diperoleh yaitu $10,54 \%$. Nilai tersebut menunjukkan sampel Sargassum sp. yang berupa simplisia kering dapat bertahan lama apabila disimpan dalam jangka panjang karena kadar air kurang dari 10\%, menurut Winarno (1997) kadar air yang terkandung dalam suatu bahan kurang dari 10\% menandakan kestabilan optimum bahan akan tercapai dan pertumbuhan mikroba dapat dikurangi. Penetapan kadar air berguna untuk mengetahui ketahanan suatu bahan agar dapat diperkirakan cara penyimpanan terbaik bagi sampel untuk menghindari pengaruh aktivitas jamur (mikroba). Beberapa peneliti melaporkan bahwakadarair S. polycystumyaitu 26,25\% (Diachanty et al. 2017) dan S. hystrix var. fluitans 14,33\% (Solarin et al. 2014). Kandungan air pada bahan pangan yang dikeringkan akan mengalami penurunan lebih tinggi dan menyebabkan pemekatan dari bahan-bahan yang tertinggal salah satunya mineral.

Penentuan kadar abu merupakan salah satu cara menentukan adanya mineral atau senyawa anorganik dalam suatu bahan. Hasil menunjukkan kadar abu Sargassum sp. yaitu 52,74\%. Kadar abu yang tinggi pada makroalga laut dipengaruhi oleh adanya garam dan mineral lain yang menempel misalnya $\mathrm{Na}, \mathrm{Ca}, \mathrm{K}$ dan $\mathrm{Mg}$ (Yuniarti et al. 2013; Yulius et al. 2016), semakin banyak kandungan mineral, maka kadar abu semakin tinggi
(Nasruddin et al. 2016). Hal ini menunjukkan bahwa tingginya kadar abu pada alga cokelat Sargassum sp. berhubungan dengan kandungan mineral.

Handayani et al. (2004) melaporkan bahwa makroalga laut $S$. Crassifolium mempunyai kadar abu yang tinggi yaitu 36,93\%. Diachanty et al. (2017) menyatakan bahwa kadar abu makroalga laut $S$. polycystum yaitu $31,52 \%$. hal ini diduga berhubungan dengan cara penyerapan hara mineral, disamping sebagai bentuk adaptasi terhadap kondisi lingkungan perairan laut yang mengandung berbagai mineral dengan konsentrasi tinggi. Penyerapan hara mineral pada rumput laut dilakukan melalui seluruh permukaan talus, tidak melalui akar, sehingga penyerapan hara mineral lebih efektif. Banyaknya hara mineral yang diserap mempengaruhi kadar abu pada jaringan rumput laut, sehingga kadar abu rumput laut menjadi tinggi.

Makroalga laut merupakan sumber karbohidrat, protein dan lemak. Kadar lemak pada Sargassum sp. yaitu 0,79\%. Kandungan protein pada Sargassum sp. yaitu 2,53\%. Diachanty et al. (2017) melaporkan bahwa S. polycystum memiliki kandungan lemak $0,23 \%$ dan protein $3,64 \%$. Ratana-arporn dan Chirapart (2006) menyatakan bahwa protein dibentuk dari beberapa asam amino yang diikat oleh peptida, kandungan protein yang berbeda dalam rumput laut disebabkan oleh kandungan asam amino di dalam rumput laut.

Bahan makanan sumber lemak dapat berasal dari hewan yang disebut lemak hewani dan dapat berasal dari tumbuhtumbuhan yang disebut lemak nabati. Makroalga laut mengandung sangat sedikit lemak (Mabeau dan Fleurence 1993; Dharmanda 2002). Makroalga laut dan 
tumbuhan pada umumnya menyimpan cadangan makanannya dalam bentuk karbohidrat terutama polisakarida. Kadar karbohidrat (by difference) pada Sargassum sp. yaitu 23,77\%. Polisakarida merupakan salah satu penyusun karbohidrat. Karbohidrat umumnya memiliki keterkaitan dengan serat dalam suatu bahan.Tingginya serat dapat disebabkan oleh tingginya polisakarida pada sel rumput laut (Ma'ruf et al. 2013)

\section{Rendemen Ekstrak}

Hasil menunjukkan bahwa rendemen ekstrak etanol yaitu $0,565 \%$ dan etil-asetat $0,420 \%$. Hal ini menunjukkan bahwa komponen senyawa polar Sargassum sp. lebih banyak. Etanol merupakan pelarut yang memiliki sifat polar yang mampu mengekstraksi senyawa aktif yang larut dalam cairan ekstraseluler dan intraseluler (Harborne 1987). Besarnya rendemen ekstrak dari suatu pelarut dipengaruhi juga oleh sifat kepolaran dari pelarut, suhu, waktu ekstraksi serta tingkat kepolaran dari jumlah bahan yang diekstrak yang memiliki polaritas yang sama (Yim et al. 2009). Rendemen pada pelarut $\mathrm{n}$-heksane yaitu $0,265 \%$, hal tersebut menunjukkan bahwa senyawa non -polar tidak banyak terdapat pada alga cokelat Sargassum sp.

\section{Komponen Bioaktif}

Analisis fitokimia merupakan langkah awal yang digunakan untuk memberikan informasi jenis senyawa bioaktif yang terkandung dalam tanaman. Informasi mengenai komponen aktif sangat penting untuk memprediksi komponen aktif yang memiliki manfaat bagi tubuh manusia. Tumbuhan yang diuji dapat berbentuk seperti segar, kering, serbuk, ekstrak dan bentuk sediaan (Harborne 1987). Senyawa bioaktif yang terkandung pada Sargassum sp. diuji secara kualitatif berdasarkan perubahan warna atau endapan yang terbentuk sebagai respon terhadap reagen yang diberikan. Adanya komponen bioaktif Sargassum sp. disajikan pada Tabel 2.

Berdasarkan hasil uji fitokimia (Tabel 2) ekstrak etanol dan n- heksan Sargassum sp. menunjukkan hasil positif terhadap senyawa alkaloid pada pereaksi wagner dan Dragendroff, namun ekstrak etil asetan menunjukan hasil negatif baik pada pereaksi mayer, wagner dan Dragendroff. Alkaloid berfungsi sebagai antibiotik dan antiimflamasi yang dapat mengurangi rasa nyeri, melancarkan peredaran darah, memulihkan stamina setelah melahirkan serta mencegah terjadinya infeksi pada bagian rahim (Sudarsono 2002).

Ekstrak etil aetat Sargassum sp. menunjukkan hasil positif terhadap senyawa fenol hidrokuinon, sedangkan ekstrak etanol dan $\mathrm{n}$-heksan menunjukan hasil negatif terhadap senyawa fenol. Senyawa fenol dapat mengurangi risiko beberapa penyakit kronis karena bersifat inflamatori, antioksidan,

Tabel 2 Hasil uji fitokimia ekstrak Sargassum sp.

(Table 2 The result of phytochemical assay of Sargassum sp. extract)

\begin{tabular}{ccccc}
\hline $\begin{array}{c}\text { Metabolit sekunder/ } \\
\text { Secondary metabolites }\end{array}$ & $\begin{array}{c}\text { Etanol/ } \\
\text { Ethanol }\end{array}$ & $\begin{array}{c}\text { Etil asetat/ } \\
\text { Ethyl acetate }\end{array}$ & $\begin{array}{c}\mathrm{n} \text {-heksan/ } \\
n \text {-hexane }\end{array}$ & $\begin{array}{c}\text { Hasil uji positif/ } \\
\text { Test results positive }\end{array}$ \\
\hline Alkaloids & & & & \\
a. Mayer & + & - & + & White sediment \\
b. Wagner & - & - & - & - \\
c. Dragendroff & - & - & - & - \\
Flavonoids & - & - & - & - \\
Phenol hydroquinone & - & + & - & Dark green/green \\
Saponin & - & - & - & - \\
Tanin & - & - & - & - \\
Steroids & - & - & - & Red \\
Triterpenoids & + & - & + & \\
\hline
\end{tabular}


detoksifkasi karsinogenik dan antikolesterol (Chen dan Blumberg 2007). Etil asetat merupakan pelarut semi polar yang dapat melarutkan komponen senyawa antioksidan yang bersifat polar maupun non-polar sehingga menghasilkan beragam senyawa antioksidan yang memiliki aktivitas sangat kuat walaupun rendemennya rendah dibandingkan dengan pelarut polar (Tensiska et al. 2001). Putri (2014) melaporkan bahwa Ekstrak alga cokelat Sargassum sp. mengandung senyawa flavonoid, saponin, fenol, steroid dan triterpenoid. Senyawa bioaktif dapat ditentukan melalui uji fitokimia serta memiliki peran penting dalam aktivitas antioksidan (Winarsi 2007).

Sargassum sp. yang di ekstrak dengan etanol, etil asetat dan n-heksan menunjukan hasil negatif terhadap senyawa saponin, tanin dan steroid. Ekstrak etanol dan nheksan Sargassum sp. menunjukkan hasil positif terhadap senyawa triterpenoid namun ekstrak etil asetat Sargassum sp. menunjukan hasil negatif terhadap senyawa triterpenoid, senyawa triterpenoid memiliki aktivitas sebagai senyawa antibakteri. Senyawa steroid/ triterpenoid dapat menghambat pertumbuhan bakteri (Rosyidah et al. 2010).

\section{Hasil Aktivitas Antioksidan}

Antioksidan didefinisikan sebagai zat yang dapat mencegah terjadinya reaksi autooksidasi radikal bebas dalam oksidasi lipid (Septiana dan Asnani 2013). Kemampuan ekstrak dalam menghambat antioksidan ditentukan berdasarkan nilai $\mathrm{IC}_{50}$. Nilai tersebut menunjukkan konsentrasi sampel yang dibutuhkan untuk mengurangi aktivitas radikal bebas DPPH 50\% (Latteä dan Kolodziej 2004; Molyneux 2004).
Hasil pengujian aktivitas antioksidan menunjukkan bahwa ketiga ekstrak Sargassum sp. dan standar vitamin C memiliki aktivitas yang berbeda. Ekstrak etil asetat memiliki aktivitas yang paling kuat dengan nilai $\mathrm{IC}_{50} 68,89 \pm 5,36 \mathrm{mg} / \mathrm{L}$. Bahriul et al. (2014) menyatakan bahwa nilai $\mathrm{IC}_{50}$ kurang dari $50 \mathrm{mg} / \mathrm{L}$ tergolong memiliki aktivitas antioksidankuat, $\quad 50-100 \mathrm{mg} / \mathrm{L}$ sedang, 150-200 mg/L lemah dan lebih dari $200 \mathrm{mg} / \mathrm{L}$ sangatlemah. Nilai $\mathrm{IC}_{50}$ yang rendah menunjukkan kemampuan yang kuat dari ekstrak untuk berperan sebagai donor atom hidrogen (Sarini et al. 2014). Kemampuan scavenging yang tinggi berkaitan dengan kelompok hidroksil yang ada pada senyawa fenolik (Mehdinezhad et al. 2016). Ekstrak etanol memiliki aktivitas antioksidan yang lemah dengan nilai $\mathrm{IC}_{50} 239,51 \pm 10,60 \mathrm{mg} / \mathrm{L}$.

Senyawa fenolik merupakan salah satu jenis antioksidan dalam bahan pangan. Senyawa fenolik terbukti sebagai sumber antioksidan yang efektif, menahan radikal bebas dan pengkelat ion logam. Aktivitas antioksidan berhubungan dengan senyawa fenol (Meskin et al. 2002).Tingginya aktifitas antioksidan pada ekstrak etil asetat mengindikasikan adanya senyawa fenol pada ekstrak

Perbandingan aktivitas antioksidan pada pelarut yang berdeda menunjukkan nilai yang relatif berbeda. perbedaan pelarut memberikan pengaruh terhadap aktivitas antioksidan. Ekstrak etil asetat memiliki nilai aktivitas antioksidan yang kuatekstrak etanol dan $\mathrm{n}$-heksan memiliki nilai aktivitas antioksidan yang masuk dalam kategori lemah dan sangat lemah. Pelarut etil asetatlebih banyakmengandung senyawa isoflavon baik non-polar (aglikon) maupun polar (glikon),ekstrak etil asetat memberikan hasil

Tabel 4 Hasil Uji Aktivitas Antioksidan dan total fenol ekstrak Sargassum sp.

(Table 4 Antioxidant activity and total phenol of Sargassum sp. extract)

\begin{tabular}{ccc}
\hline Extract & Total phenol content $(\mathrm{mg} \mathrm{GAE} / \mathrm{g})$ & Antioxidant activity $\left(\mathrm{IC}_{50}\right)(\mathrm{mg} / \mathrm{L})$ \\
\hline Ethanol & $563.22 \pm 15.54$ & $239.51 \pm 10.60$ \\
Ethyl acetate & $1.348,18 \pm 2.57$ & $68.89 \pm 5.36$ \\
n-hexane & $30.610 \pm 28.28$ & $148.16 \pm 2.5$ \\
Vitamin C & - & 1.30 \\
\hline
\end{tabular}


terbaik dibandingkan dengan ekstrak etanol danekstrak n-heksana (Tensiska et al. 2001).

Nilai aktivitas antioksidan yang tinggi pada ekstrak etil asetat berkorelasi positif terhadap kandungan total fenol. Hal ini terbukti dengan adanya hasil uji fitokimia ekstrak etil asetat memiliki senyawa fenol dan diperkuat dengan hasil uji kandungan total fenol. Molyneux (2004) menyatakan jika di dalam suatu bahan memiliki kandungan senyawa fenol maka aktivitas antioksidan dalam bahan tersebut juga tinggi.

\section{Analisis Korelasi Kandungan Total Fenol dengan Aktivitas Antioksidan}

Senyawa fenol adalah senyawaan kimia yang berpotensi sebagai antioksidan, tetapi aktivitas antioksidan tidak hanya disebabkan oleh senyawaan fenol. Senyawaan triterpena pentasiklik, vitamin C, zat warna seperti klorofil, senyawaan sulfur, ataupun nitrogen dapat berperan sebagai antioksidan (Khamsah et al. 2006). Analisis korelasi antara total fenol dan aktivitas antioksidan metode DPPH bertujuan menentukan kedekatan hubungan antara total fenol dan aktivitas antioksidan.

Berdasarkan hasil analisis diketahui bahwa kandungan total fenol memiliki hubungan korelasi yang positif dan kuat antara total fenol dan aktivitas antioksidan. Hubungan antara kandungan total fenol (x) dan IC $_{50}$ ekstrak Sargassum sp. mempunyai koefisien korelasi $\mathrm{R}^{2}=0.997$ pada aktivitas antioksidan dengan metode DPPH. Hasil tersebut menunjukkan bahwa 99\% aktivitas antioksidan merupakan hasil kontribusi kelompok senyawa fenol, sisanya sebesar $1 \%$ ditentukan oleh variabel lain yang tidak diketahui, diduga $1 \%$ tersebut merupakan sumbangan dari senyawa lain yang bukan termasuk dalam golongan senyawa fenolik namun memiliki aktivitas antioksidan. Adanya kandungan fenolik diduga akan memberikan efek antioksidan yang cukup besar.

Rafi et al. (2012) melaporkan bahwa senyawa fenol sebagai metabolit sekunder dalam tanaman yang berpotensi sebagai antioksidan. Hal ini disebabkan oleh keberadaan gugus hidroksil dalam senyawaan fenol. Gugus hidroksil dapat berfungsi sebagai penyumbang atom hidrogen ketika bereaksi dengan senyawa radikal melalui mekanisme transfer elektron sehingga proses oksidasi dihambat. De Quiros et al. 2010; Lopez et al. 2011 menyatakan bahwa senyawa fenol memiliki aktivitas antioksidan yang diketahui sebagai asam fenol yang terdapat

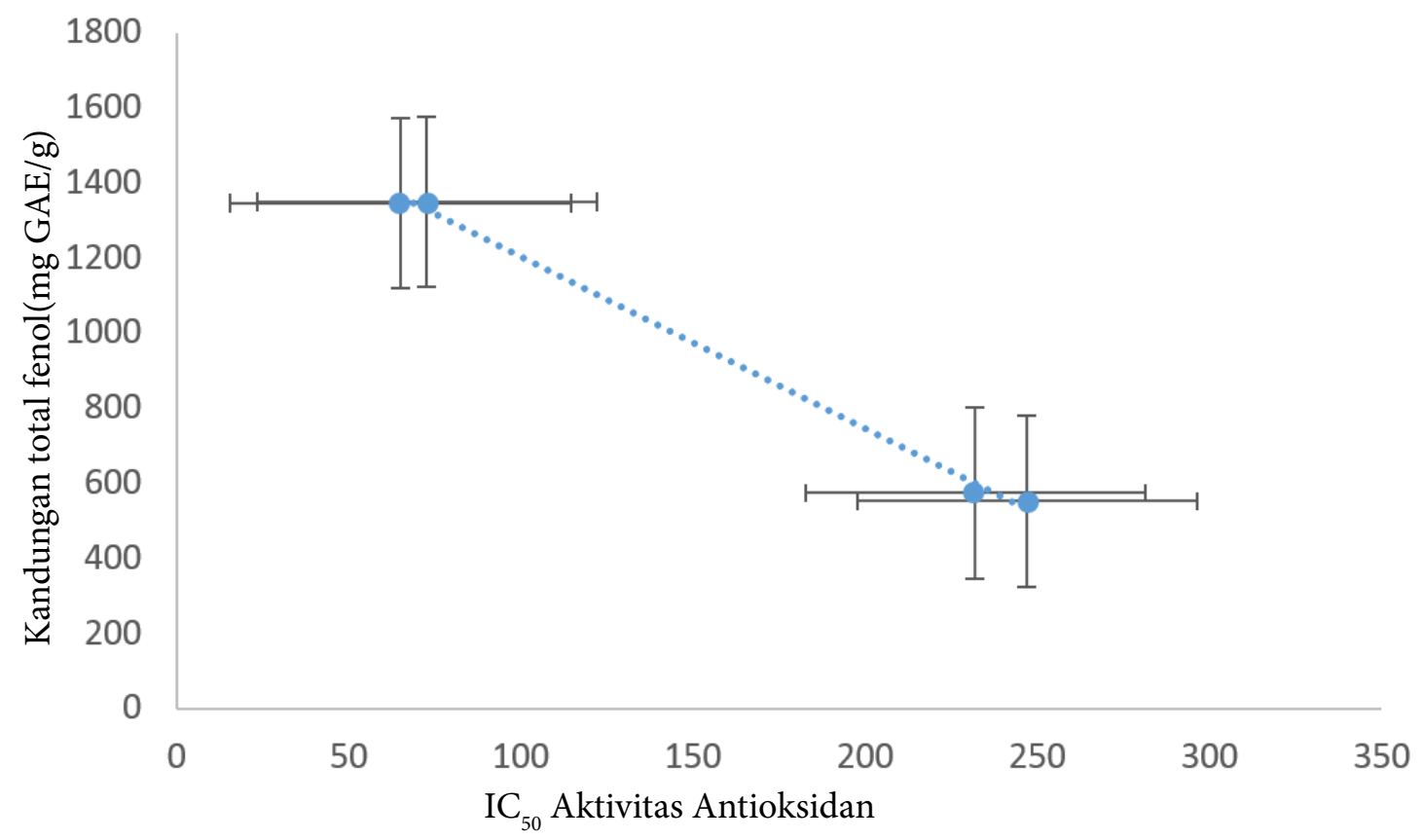

Gambar 4 Hubungan total fenol dengan aktivitas Antioksidan

(Figure 4 correlation of total phenol with antioxidant activity) 
pada makroalga laut yang meliputi katekin, epikatekin, EGCG, quersetin dan lain-lain. Hubungan antara kandungan total fenol danaktivitas antioksidan metode DPPH pada ekstrak Sargassum sp. dapat disajikanpada Gambar 4.

Dari hasil tersebut dapat dinyatakan bahwa aktivitasantioksidan metode DPPH berkorelasi positif dengan total fenol sehingga aktivitas antioksidan disebabkan oleh kandungan total fenol dari alga cokelat Sargassum sp.

\section{KESIMPULAN}

Komposisi kimia yang dominan pada alga cokelat Sargassum sp. yaitu abu dan karbohidrat. Sargassum sp. mengandung alkaloid, fenol dan triterpenoid. Sargassum sp. memiliki aktivitas antioksidan yang kuat pada ekstrak etil asetat. ektrak Sargassum sp. dapat dijadikan sumber antioksidan.

\section{UCAPAN TERIMA KASIH}

Terima kasih kepada Direktorat Riset dan Pengabdian Masyarakat, Direktorat Jenderal Penguatan Riset dan Pengembangan, serta Kementerian Riset, Teknologi, dan Pendidikan Tinggi yang telah membantu penelitian ini, dengan skim Penelitian Kerjasama Antar Penguruan Tinggi (PKPT) atas nama Mohamad Gazali dengan nomor: 026/E3.2/LT/2017.

\section{DAFTAR PUSTAKA}

Andarwulan S, Fardiaz, Apriyanto P, Haryadi, Shetty NK. 1999. Mobilization of primary metabolites and phenolics during natural fermentation in seeds of Pangiumedule Reinw. Process Biochemistry. 35: 197-204.

[AOAC] Association of Official Analytical Chemist. 2005. Official Method of Analysis of The Association ofOfficial Analytical of Chemist. Arlington: The Association of Official Analytical Chemist, Inc.

Arnold TM. TargettNM, 2000. Evidence formetabolic turnover of polyphenolics in tropicalbrown algae. Journal of Chemical Ecology. 26: 1393-1408.

Bahriul P, Rahman N, Diah AWM. 2014. Uji aktivitas antioksidan ekstrak daun salam (Syzygium polyanthum) dengan menggunakan 1,1-difenil-2pikrilhidrazil. Jurnal Akademia Kimia. 3(3): 143-149.

Budhiyanti SA, Raharjo S, Djagal W. Marseno, Iwan YB. Lelana, 2011. Free radical scavenging,metal chelating and singlet oxygen quenchingactivity of fractionated brown seaweed Sargassumhystrix Extract. Journal of Biological Science. 11: 288-298.

Chan EWC, Lim YY, Omar M. 2007. Antioxidant and antibacteria activity of leaves of Etlingera species (Zingiberaceae) in Peninsular Malaysia. FoodChemistry. 104(4): 1586-1593.

Cardoso MS, Pereira OR, Seca AML, PintoDCGA, Silva AMS. 2015. Seaweeds aspreventive agents for cardiovasculardiseases: from nutrients to functionalfoods. Marine Drugs. 13: 68386865.

Chen CYO, Blumberg JB. 2007. Phytochemicalcomposition of nuts. Asia Pasifc Journal of Clinical Nutrition. 17(1): 329-332.

De Quiros ARB, Frecha FS, Vidal PAM, Lopez HJ. 2010. Antioxidant compounds in edible brown seaweeds. European Food Research and Technology. 231: 495-498.

Diachanty S, Nurjanah, Abdullah A. 2017. Aktivitas antioksidan berbagai jenis rumput laut

coklat dari Perairan Kepulauan Seribu. Jurnal Pengolahan Hasil Perikanan Indonesia. 20(2): 305-318.

Dolorosa TM, Nurjanah, Purwaningsih S, Effionora A, Taufik H. 2017. Kandungan senyawa bioaktif bubur rumput laut Sargassum plagyophyllum dan Eucheuma cottonii sebagai bahan baku krim pencerah kulit. Jurnal Pengolahan Hasil Perikanan Indonesia. 20(3): 633-644.

Firdaus M. 2013. Indeks aktivitas antioksidan ekstrak rumput laut coklat Sargasum aquifolium. Jurnal Pengolahan Hasil Perikanan Indonesia. 16(1): 42-47.

Fleurence J. 1999. Seaweed proteins: biochemical,nutritional aspects and potential uses. Review of Trends in Food Science and Technology. 10: 25-28.

Handayani T, Sutarno, Dwisetyawan A. 2004. 
Analisis Komposisi Nutrisi Rumput Laut Sargassum crassifolium J. Agardh. Biofarmasi 2 (2): 45-52,

Harborne JB. 1987. Metode Fitokimia. Edisi ke-2. Padmawinata K, Soediro I,penerjemah. Bandung (ID): Institut Teknologi Bandung. Terjemahan dari: Phytochemical Methods.

Jeeva S, Marimuthu J, Domettila C, Anantham, Mahesh M. 2012. Preliminary phytochemical studies on some selected seaweeds from Gulf of Mannar, India. Asian Pacifc Journal of Tropical Biomedicine. S30-S33

Khamsah SM, Akowah G, Zhari I. 2006. Antioxidant activity and phenolic content of orhosiphon stamineus Benth from different geofraphical origin. Journal of Sustainability Science and Management. 1: 14-20.

Kohen R, NyskaA. 2002. Invited review: Oxidation of biological systems: Oxidative stressphenomena, antioxidants, redox reactions andmethods for their quantification. Toxicologic Pathology. 30: 620-650.

Koivikko R. 2008. Brown algal phlorotannins: improving and applying chemical methods. University of Turku, Turku, Finland, pp: 1-61. http://www.doria.fi/ bitstream/handle/10024/36054/AI381. pdf? sequence $=1$

Koivikko R, Loponen J, Honkanen T, Jormalainen V. 2005. Contents of soluble, cell-wallboundand exuded phlorotannins in the brown alga fucus vesiculosus, with implications on theirecological functions. Journal of Chemical Ecology. 31: 195-212.

Lampe JW. 1999. Health effects of vegetables and fruits: assessing mechanism of action in human experimental studies. American Journal Clinical Nutrition. 70: 475-490.

Latteä KP,Kolodziej H. 2004. Antioxidant properties of phenolic compounds from Pelargonium reniforme. Journal of Agricultural and Food Chemistry. 52(7): 4899-4902.

Lopez A, Rico M, Rivero A and Tangil MS. 2011. The effect of solvents on the phenolic contents and antioxidant activity of Stypocaulon scoparium algae extracts.
Food Chemistry. 1104-109.

Luthfiana N, Nurjanah, Mala N, Effionora A, Taufik H. 2017. Karakterisasi sediaan krim tabir surya dari bubur rumput laut Eucheuma cottonii dan Sargassum sp. Jurnal Pengolahan Hasil Perikanan Indonesia. 19(3): 183-195

Maharany P, Nurjanah, Ruddy S, Effionora A, Taufik H. 2017. Kandungan senyawa bioaktif rumput laut Padina australis dan Eucheuma cottonii sebagai bahan baku krim tabir surya. Jurnal Pengolahan Hasil Perikanan Indonesia. 20(1): 10-17

Ma'ruf WF, Ratna I, Eko ND, Eko S, UlfahA. 2013. Profil rumput laut Caulerpa racemosa dan Gracilaria verrucosa sebagai edible food. Jurnal Saintek Perikanan. 9(1): 68-74.

Matanjun P, Mohamed S, Mustapha NM, Muhammad K, MingCH. 2008. Antioxidantactivities and phenolics content of eight species ofseaweeds from north Borneo. Journal of Applied Phycology. 20: 367-373.

Mehdinezhad N, Ghannadi A, YegdanehA. 2016. Phytochemical and biologicalevaluation of some Sargassum speciesfrom Persian Gulf. Research in Pharmaceutical Sciences. 11(3): 243-249.

Meskin MS, Bidlack WR, Davies AJ, Omaye ST. 2002. Phytochemical Nutrition and Health. London-New York. CRC Press,

Molyneux P. 2004. The Use of Stable Free Radical Diphenylpicrylhydrazyl (DPPH) for Estimating Antioxidant Activity. Songklanakarin Journal of Science and Technology. 26: 211-219.

Mudgal VN, Madaan A. Mudgal, Misra. 2010. Dietary polyphenols and human health. Asian Journal Biochemistry. 5: 154-162.

Nagappan H, Pee PP, Kee SHY, Ow JT, Yan SW, Chew LY, Kong KW. 2017. Malaysianbrown seaweeds Sargassum siliquosumand Sargassum polycystum: low densitylipoprotein (LDL) oxidation, angiotensinconverting enzyme (ACE), $\alpha$-amylase anda-glucosidase inhibition activities. FoodResearch International. 1-9.antioxidant activity. Journal Science Technology. 26(2): 211-219.

Nagai T, YukimotoT. 2003. Preparation 
andfunctional properties of beverages made from seaalgae. Food Chemistry. 81: 327-332.

Naczk M, Shahidi F. 2006. Phenolics in cereals, fruits and vegetables: Occurrence,extraction and analysis. Journal of Pharmacology Biomedic Analysis. 41: 1523-1542.

Nasruddin, Asikin AN, Kusumaningrum I. 2016. Pengaruh konsentrasi $\mathrm{KOH}$ terhadap karakteristik karagenan dari Kappaphycus alvarezii. Jurnal Ilmu Perikanan Tropis. 21(2): 55-63.

Nufus C, Nurjanah, Abdullah A. 2017. Karakteristikrumput laut hijau dari perairan kepulauan seribu dan sekotong Nusa Tenggara Barat sebagai antioksidan. Jurnal Pengolahan Hasil Perikanan Indonesia. 20(3): 620-630.

Nurjanah, Nurilmala M, Hidayat T, Sudirjo F. 2015. Characteristics of Seaweed as Raw Materials for Cosmetics. Aquatic Procedia. 7: 177-180.

Olabarria C, RodilIF, Incera M, TroncosoJS. 2009. Limited impact of Sargassum muticum onnative algal assemblages from rocky intertidalshores. Marine Environmental Research. 67: 153-158.

Padua D, Rocha E, Gargiulo D, RamosAA. 2105. Bioactive compounds frombrown seaweeds: phloroglucinol,fucoxanthin and fucoidan as promisingtherapeutic agents against breast cancer. Phytochemistry Letters. 14: 91-98.

Putri AM. 2014. Ekstraksi Rumput laut coklat sargassum sp. (CP 01) dan pengujian ekstrak sebagai Inhibitor tirosinase. [skripsi]. Bogor (ID): Fakultas Perikanan dan Ilmu Kelautan, Institut Pertanian Bogor.

Rafi M, Widyastusti N, Elly S, Darusman LK. 2012. Aktivitas Antioksidan, Kadar Fenol Dan Flavonoid Total Dari Enam Tumbuhan Obat Indonesia. Jurnal Bahan Alam Indonesia. 8: 10-20.

Ragan MA, GlombitzaKW. 1986. Phlorotannins, Brown Algal Polyphenols. In: Progress in Phycological Research Biopress. pp: 129-241.

Ratana-arporn P, Chirapart A. 2006. Nutritional evaluation of tropical greenseaweeds Caulerpa lentillifera and Ulva reticulata. Kasetsart Journal of Natural Science. 40: 75-83.

Rosyidah K, Nurmuhaimina SA, Komari N,Astuti MD. 2010. Aktivitas antibakterifraksi saponin dari kulit batang tumbuhankasturi (Mangifera casturi). Bioscientiae. 7(2): 29-38.

Sarini AW, Aishah HN, Zaini NM. 2014. Determination of antioxidant activity forseven types of macroalgae. International Conference on Food Engineering and Biotechnology. 65: 51-56.

Septiana AT, Asnani A. 2013. Aktivitas antioksidan ekstrak rumput laut Sargassum duplicatum. Jurnal Teknologi Pertanian. 14(2): 79-86.

Sudarsono, Gunawan D, Wahyono S, DonatusIA, Purnomo. 2002, Tumbuhan Obat II,Sifat-sifat dan penggunaan. Yogyakarta (ID): Universitas Gajah Mada.

Syad AN, Shunmugiah KP, Kasi PD. 2013. Seaweed as nutritional supplements: analysis of nutritional profle, physicochemical properties andproximate composition of G.acerosa and S.wightii. Biomedicine and Preventive Nutrition. 3: 139-144.

Valdebenito H, Bittner M, Sammes PG, Silva $\mathrm{M}$ and Watson WH. 1982. A compound with antimicrobial activity isolated fromthe red seaweed Laurencia chilensis. Phytochemistry. 21: 1456-1457.

Winarsi H. 2007. Antioksidan Alami dan Radikal Bebas. Yogyakarta (ID): Kanisius.

Wong SP, Leong LP, Koh JHW. 2006. Antioxidant activities of aqueous extractsof selected plants. Food Chemical. 99: 775-783.

Yim HS, Chye FY, Ho SK, Ho CW. 2009. Phenolic profiles of selected edible wild mushrooms as affected by extraction solvent, time and temperature. Asian Journal of Food and Agro Industry. 2(3): 392-401.

Yuan YV, Walsh NA. 2006. Antioxidant and antiproliferative activities of extracts from a variety of edible seaweeds. Food and Chemical Toxicology. 44: 1144-1150.

Yulius F, Kusumaningrum I, Hasanah R. 2016.Pengaruh lama perebusan terhadap 
mutukaraginan dari rumput laut (Kappaphycus alvarezii). Jurnal Ilmu Perikanan Tropis. 21(2): 41-47.

Yuniarti DW, Sulistiyati TD, Suprayitno E. 2013. Pengaruh suhu pengeringan vakumterhadap kualitas serbuk albumin ikangabus (Ophiocephalus striatus). Student Journal Universitas Brawijaya. 1(1): 1-9.

Winarno. 1997. Kimia Pangan dan Gizi. Jakarta (ID): Gramedia.

Yanuarti R, Nurjanah N, Anwar E, Hidayat T. 2017. Profil fenolik dan aktivitas antioksidan dari ekstrak rumput laut Turbinaria conoides dan Eucheuma cottonii. Jurnal Pengolahan Hasil Perikanan Indonesia. 20(2): 230-237.

Zubia M, PayriC, DeslandesE. 2008. Alginate,mannitol, phenolic compounds and biologicalactivities of two rangeextending brown algae, Sargassum mangarevense and Turbinaria ornata (Phaeophyta: Fucales), from Tahiti (FrenchPolynesia). Journal of Applied Phycology. 20: 1033-1043. 